\title{
Export Tax Reform and the Competitiveness of Imported Soybeans in China
}

\author{
Andrew Muhammad ${ }^{1, * *}$ (iD) and Constanza Valdes ${ }^{2, * *}$ \\ ${ }^{1}$ Department of Agricultural and Resource Economics, University of Tennessee Institute of Agriculture, Knoxville, Tennessee, \\ USA and ${ }^{2}$ Economic Research Service, U.S. Department of Agriculture, Washington, D.C., USA \\ ${ }^{\star}$ Corresponding author. Email: amuhammad@utk.edu \\ ${ }^{* *}$ The views expressed are those of the authors and may not be attributed to the Economic Research Service or the U.S. \\ Department of Agriculture.
}

\begin{abstract}
Export tax reform in Argentina could improve its competitiveness in China's soybean market, displacing exports from competing countries like Brazil and the United States. We examined the factors that determine China's demand for imported soybean products and how export taxes could affect exporting countries. Using import demand and vector autoregression estimates, we conducted simulations of China's import demand assuming the elimination of export taxes in Argentina. Results indicated that Argentine soybean products could realize gains in the Chinese market, but only in the short run. Projected import demand changes in the long run were insignificant for all exporting countries.
\end{abstract}

Keywords: Argentina; Brazil; China; demand; export taxes; imports; soybeans; United States

JEL Classifications: F13; Q11; Q17

\section{Introduction}

In the wake of a currency devaluation and debt crisis in 2002, the government of Argentina reinstituted export taxes on a wide range of products, including soybeans, with the goal of increasing fiscal revenues and limiting the devaluation's impact on inflation (Regúnaga and Rodriguez, 2015). Initial rates were set at $13.5 \%$ for soybeans and $5 \%$ for soybean oil. In the years that followed, the government continued to increase export tax rates. By 2007, export taxes on soybeans and soybean oil were at their highest levels, $35 \%$ and $32 \%$, respectively. There was even an attempt to further increase soybean export taxes in 2008, which was never implemented because of nationwide protests by farmers (Pirovano, 2009; Regúnaga and Rodriguez, 2015; Sandoval and Joseph, 2015).

Argentina has a long history of taxing agricultural exports. Taxes on soybean exports have been particularly high relative to other agricultural products given their importance to the overall economy and foreign exchange earnings. Despite this history, a newly elected government in 2015 has been committed to economic reforms, implementing policies to decrease or eliminate exports taxes on principal agricultural commodities such as dairy, beef, corn, wheat, and soybeans (Sullivan and Nelson, 2017). In 2016, there was an immediate export tax reduction of 5\% on soybean products, but because of fiscal concerns it was later determined that further reductions would be delayed until 2018. The plan was to reduce soybean export taxes by $0.5 \%$ per month from January 2018 until December 2019 (Sandoval, 2016; Sullivan and Nelson, 2017). However, because of a worsening economy, the Argentine government imposed another

\footnotetext{
${ }^{\ddagger}$ An error in this article has been corrected. Please see 10.1017/aae.2019.24
} 
suspension of export tax reductions and announced in September 2018 that soybeans and soybean products will be subject to a fixed and variable export tax rate until December 2020. Currently, the fixed rate for all soybean products is $18 \%$, and the variable rate is 4 Argentine pesos per U.S. dollar in export value, which varies in percentage terms based on the exchange rate (Sandoval, 2018).

Argentina's attempt at export tax reform raises questions about the performance and competitiveness of its soybean sector. Although rate reductions could improve farmer profitability, the global effects of this policy are not obvious. Argentina is the world's third leading soybean exporter, but it exports are a fraction of the exports from the United States and Brazil (e.g., about $20 \%$ of Brazil's exports in 2016). Given Argentina's position in the global soybean trade, it is conceivable that a reduction or elimination of export taxes could improve its global competitiveness, displacing soybean exports from countries like the United States and Brazil. However, because Argentina exports significantly less than the United States and Brazil, it is also conceivable that its export tax reform could have little effect on competing countries and global markets. An important objective of this study is to determine which outcome (significant impact as opposed to little effect on global markets) is the most likely.

China's soybean market provides the ideal case for examining how Argentina's export tax reform will affect major exporting countries. China is the largest foreign soybean market and is particularly important to global export disappearance (Chen, Marchant, and Muhammad, 2012). For instance, China imported more than 80 million metric tons (MT) of soybeans in 2016, accounting for almost two-thirds of global soybean trade; its imports from Argentina were 8 million MT, accounting for more than $80 \%$ of Argentina's export disappearance. China is also important to the United States and Brazil, accounting for $60 \%-80 \%$ of soybean exports from these countries. ${ }^{1}$

In this study, we examine the factors that determine China's demand for imported soybean products. Of particular importance is the price competition between Argentina, Brazil, and the United States and how the elimination of export taxes in Argentina could affect Chinese imports. A primary objective of this study is to estimate China's demand for imported soybeans and soybean oil differentiated by exporting source. ${ }^{2}$ We employ an estimation procedure that allows for deriving unconditional import demand elasticities, which can account for both trade diversion and creation when examining the impact of price-changing policies. These estimates are then used to project the impact of Argentina's export tax reform on China's import demand by exporting source.

Although Argentina exports significantly less than the United States and Brazil, a price shock in Argentina could still affect soybean prices globally. Taking this into account, we assess the longrun price relationship among soybean products in Argentina, Brazil, and the United States, as well as in China, using a vector autoregression (VAR) model. Given the import demand and VAR estimates, we conduct import demand projections assuming the following: (1) prices in Argentina are the only prices affected by its export tax reform; (2) prices in Brazil, the United States, and China experience the largest possible response to Argentina's export tax reform based on the estimated relationships from the VAR procedure; and (3) prices in all countries reached their long-run equilibrium as specified by the estimated relationships from the VAR procedure. Monte Carlo simulations are used to derive confidence intervals for all projections based on the covariance matrix of the estimated import demand coefficients.

Overall, most studies of export tax reform in Argentina have been relatively broad in scope (Bouët, Estrades, and Laborde, 2014; Deese and Reeder, 2007; Meilke, Wensley, and Cluff, 2001). Cicowiez, Díaz-Bonilla, and Díaz-Bonilla (2010) examined the long-run effect of export tax elimination on economic growth and poverty mitigation in Argentina, and Toulan (2002) assessed the impact of export tax, import tariff, and export subsidy eliminations on world demand for Argentine exports. More specific to Chinese soybean demand, Taheripour and Tyner (2018)

\footnotetext{
${ }^{1}$ Data are from the United Nations Comtrade database (https://comtrade.un.org/). Percentages do not include soybean oil and soybean meal, which are significantly smaller by comparison.

${ }^{2}$ China imports negligible amounts of soybean meal.
} 


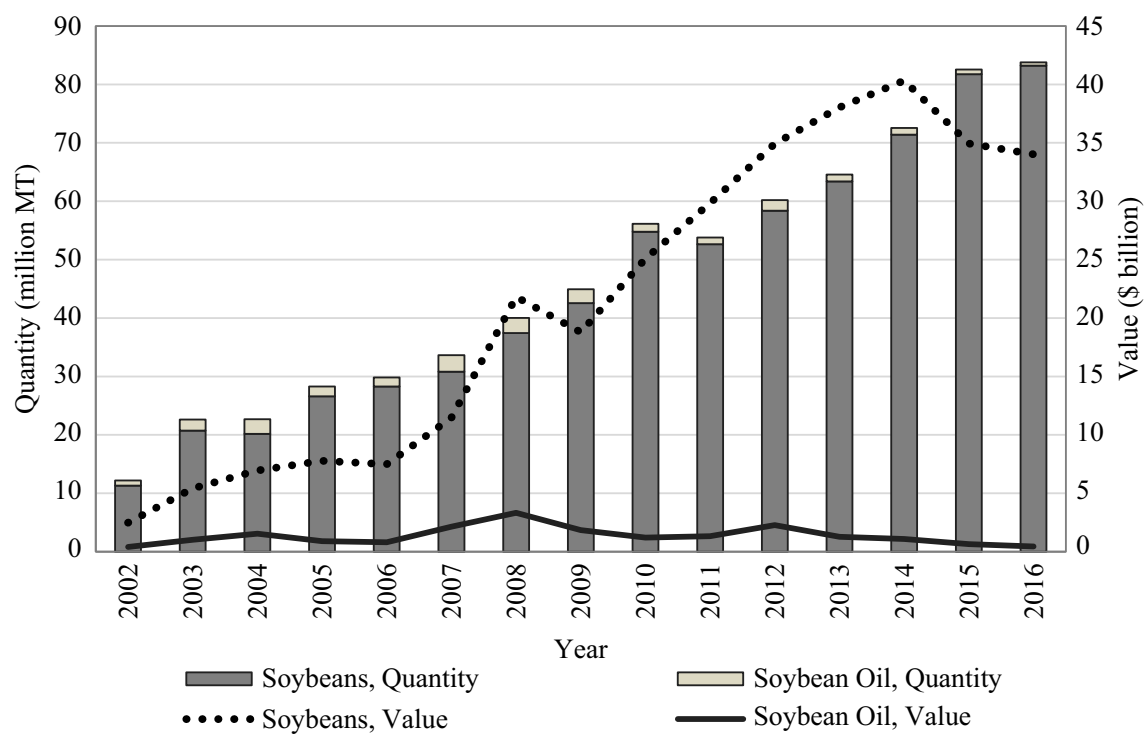

Figure 1. China's soybean and soybean oil imports: 2002-2016. Source: World Trade Atlas, Global Trade Information Services Inc.

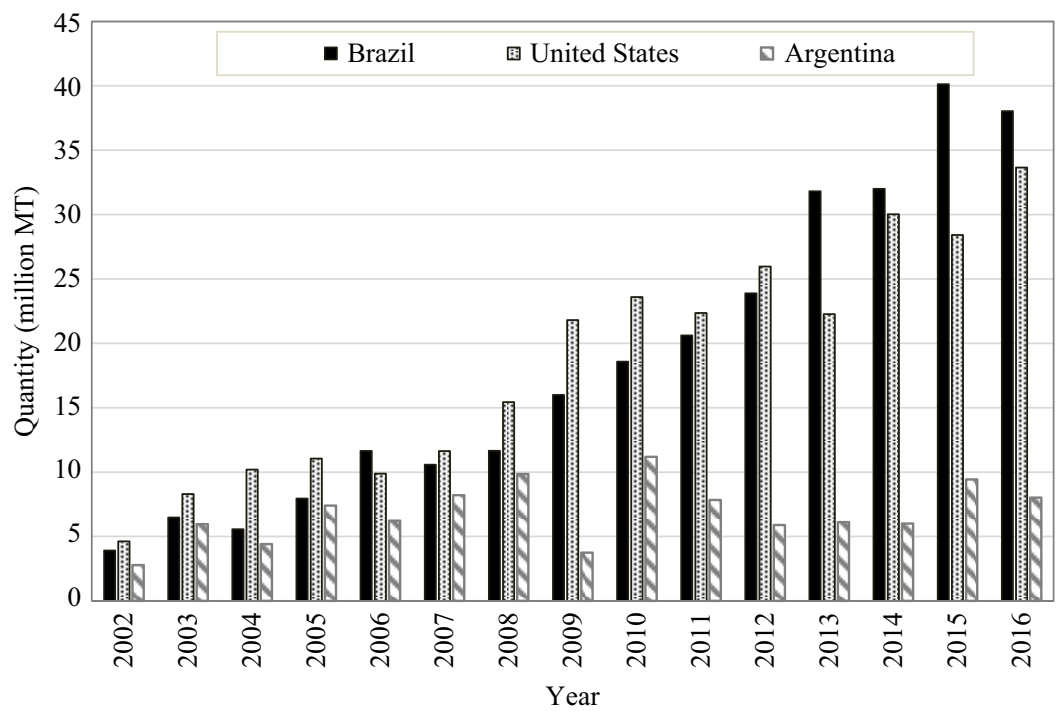

Figure 2. China's soybean imports by source: 2002-2016. Source: World Trade Atlas, Global Trade Information Services Inc.

and Muhammad and Smith (2018) examine the impact of the U.S.-China trade war on Chinese soybean imports. Studies of how export taxes in Argentina affect soybean import demand in China appear to be absent from the literature.

The remainder of this article is structured as follows. We close this section with an overview of China's soybean product imports. In Section 2, we present the model and simulation procedure. We then give an overview of the data, estimation, report estimates, and simulation results (Section 3). The final section contains a brief summary and conclusion Section 4). 
Table 1. Soybean imports in China and exporter and product shares: 2002-2016

\begin{tabular}{|c|c|c|c|c|c|c|c|c|c|}
\hline Year & $\begin{array}{c}\text { Total } \\
\text { Imports } \\
\text { (billion \$) }\end{array}$ & Soybeans & $\begin{array}{c}\text { Soybean } \\
\text { Oil }\end{array}$ & $\begin{array}{c}\text { U.S. } \\
\text { Soybeans }\end{array}$ & $\begin{array}{l}\text { Brazilian } \\
\text { Soybeans }\end{array}$ & $\begin{array}{l}\text { Argentine } \\
\text { Soybeans }\end{array}$ & $\begin{array}{c}\text { Brazilian } \\
\text { Soybean } \\
\text { Oil }\end{array}$ & $\begin{array}{c}\text { Argentine } \\
\text { Soybean } \\
\text { Oil }\end{array}$ & $\begin{array}{c}\text { ROW }^{\mathrm{a}} \\
\text { Soybean } \\
\text { Oil }\end{array}$ \\
\hline \multicolumn{10}{|c|}{ Market Share (\%) } \\
\hline 2002 & 2.89 & 85.9 & 14.1 & 33.3 & 31.3 & 21.1 & 5.3 & 8.4 & 0.5 \\
\hline 2003 & 6.43 & 84.2 & 15.8 & 34.5 & 26.2 & 23.5 & 4.2 & 10.8 & 0.8 \\
\hline 2004 & 8.51 & 81.8 & 18.2 & 39.4 & 24.2 & 18.2 & 6.4 & 11.8 & 0.0 \\
\hline 2005 & 8.69 & 89.5 & 10.5 & 36.4 & 27.4 & 25.1 & 2.0 & 8.4 & 0.0 \\
\hline 2006 & 8.29 & 90.3 & 9.7 & 32.8 & 36.4 & 19.5 & 1.7 & 7.8 & 0.2 \\
\hline 2007 & 13.61 & 84.2 & 15.8 & 31.2 & 28.6 & 23.2 & 2.3 & 12.5 & 0.9 \\
\hline 2008 & 25.15 & 86.7 & 13.3 & 33.5 & 29.0 & 23.1 & 3.7 & 8.8 & 0.8 \\
\hline 2009 & 20.63 & 91.1 & 8.9 & 45.2 & 35.6 & 8.0 & 1.9 & 6.8 & 0.2 \\
\hline 2010 & 26.29 & 95.4 & 4.6 & 43.1 & 31.0 & 18.9 & 3.1 & 0.5 & 1.0 \\
\hline 2011 & 31.16 & 95.8 & 4.2 & 40.6 & 37.9 & 14.0 & 1.9 & 1.5 & 0.8 \\
\hline 2012 & 37.20 & 93.9 & 6.1 & 41.3 & 38.2 & 9.9 & 3.0 & 2.4 & 0.7 \\
\hline 2013 & 39.31 & 96.8 & 3.2 & 33.9 & 48.7 & 9.3 & 1.2 & 1.8 & 0.3 \\
\hline 2014 & 41.42 & 97.4 & 2.6 & 39.4 & 45.4 & 8.1 & 1.1 & 1.1 & 0.4 \\
\hline 2015 & 35.59 & 98.2 & 1.8 & 35.0 & 47.7 & 11.0 & 0.4 & 1.1 & 0.3 \\
\hline 2016 & 34.47 & 98.7 & 1.3 & 39.9 & 45.2 & 9.4 & 0.7 & 0.0 & 0.7 \\
\hline
\end{tabular}

${ }^{a}$ ROW is the rest of the world.

Source: World Trade Atlas, Global Trade Information Services Inc.

\subsection{China's soybean product imports}

China's soybean and soybean oil imports are reported in Figure 1, China's soybean imports by source are reported in Figure 2, and China's import value and value shares are reported in Table 1. Since 2002, China's imports have significantly increased from $\$ 3$ billion (all dollar amounts are in U.S. dollars) to about $\$ 35$ billion (11 million MT to about 84 million MT in volume), an increase of more than 1,000\%. Overall, soybeans (HS 1201 soybeans, whether or not broken) account for the majority of China's soybean product imports. Since 2007, soybean oil (HS 1507 soybean oil and its fractions, whether or not refined, but not chemically modified) as a share of total imports has been declining, accounting for less than $2 \%$ in 2016. The share of China's soybean product imports from the United States has remained relative stable since 2002 (30\%-40\%), whereas the share of imports from Brazil has increased to about 45\% in recent years. From 2007 to 2012, the United States was China's leading foreign supplier (in volume). Since that time, Brazil has reemerged as China's leading soybean supplier. In 2016, China imported 38 million MT of soybeans from Brazil and 34 million MT from the United States, but only 8 million MT from Argentina.

Particularly interesting is the decline in imports and market share for Argentina starting in 20092010. The currency devaluation in 2002 resulted in relative stable exports to China. During the period 2002-2008, Argentina remained a leading exporter of soybean oil, reflecting the country's large and growing crushing capacity and export tax structure that favored soybean oil and biodiesel rather than soybeans. Beginning in 2009, however, a financial crisis constrained Argentina's soybean product exports. This decline was also attributable, in part, to government policies that created disincentives for agricultural production and exports and, more recently, higher returns to competing crops such as corn and wheat (Regúnaga and Rodriguez, 2015). Since recovering from a low in 2009 (4 million MT) 
to a high in 2010 (11.2 million MT), China's soybean imports from Argentina have been consistently less than 10 million MT.

\section{Methods}

\subsection{Import demand model}

We use an Armington (1969) framework (source differentiation) to model China's soybean import demand. In this context, soybeans (or soybean oil) from the $i$ th exporting country are treated as an individual good that is part of the product group imported soybeans and an imperfect substitute for soybeans from other exporting countries. ${ }^{3}$ Within and across exporting countries, there is also imperfect substitutability between products (soybeans vs. soybean oil).

Following Seale, Marchant, and Basso (2003) and Muhammad (2013), a differenced version of the Almost Ideal Demand System (AIDS) is employed for estimation (Deaton and Muellbauer, 1980). Like other differential demand systems, the differenced AIDS is linear in coefficients and is therefore easy to estimate. Additionally, first differencing variables for empirical analysis can alleviate problems of nonstationarity (Matsuda, 2005). The AIDS functional form is also suitable when there are periodic disruptions in trade because log quantities are not needed for estimation (Muhammad, 2013). We discuss the issue of modeling trade disruptions in more detail later in the section.

We denote the price and quantity of China's soybeans imports from the ith exporting country as $p_{i}$ and $q_{i}$, respectively, and China's total expenditure on all soybean imports as $E=\sum_{i=1}^{n} E_{i}$, where $E_{i}=p_{i} q_{i}$ is the value of imports from exporting country $i$ and $n$ is the total number of exporting countries/products. We also denote the import expenditure share for exporting country $i$ as $w_{i}=E_{i} / E$. Given these terms, the first-differenced AIDS is specified as follows:

$$
\Delta w_{i t}=\alpha_{i} \Delta \ln \frac{E_{t}}{P_{t}}+\sum_{j=1}^{n} \beta_{i j} \Delta \ln p_{j t}+\sum_{k=1}^{4} \gamma_{i k} d_{k}+\mu_{i t} .
$$

$\Delta w_{i t}=w_{i t}-w_{i t-1} \quad$ is the differenced import share; $\Delta \ln E_{t}=\ln E_{t}-\ln E_{t-1}$ and $\Delta \ln p_{j t}=\ln p_{j t}-\ln p_{j t-1}$ are the total expenditure and $j$ th import price in log differences; and $\Delta \ln P_{t}$ is the Divisia price index: $\Delta \ln P_{t}=\sum_{i=1}^{n} \bar{w}_{i t} \Delta \ln p_{i t}$, where $\bar{w}_{i t}=0.5\left(w_{i t}+w_{i t-1}\right)$ is the average import share between periods $t$ and $t-1$. Unlike the Stone price index, which is typically used when estimating the AIDS functional form in levels, estimates using the Divisia price index are invariant to unit of measure (Seale, Marchant, and Basso, 2003). $d_{k}$ is a quarterly binary variable, added to account for seasonality, and $\mu$ is a random disturbance term. $\alpha, \beta$, and $\gamma$ are fixed parameters to be estimated. According to theory, the following parameter restrictions should hold true: $\sum_{i} \alpha_{i}=\sum_{i} \beta_{i j}=\sum_{i} \gamma_{i k}=0$ (adding up); $\sum_{j} \beta_{i j}=0$ (homogeneity); and $\beta_{i j}=\beta_{j i}$ (symmetry).

From equation (1), we can derive the marginal import share, $\theta_{i}=\frac{\partial E_{i}}{\partial E}=\alpha_{i}+w_{i}$, which is the additional expenditure on the $i$ th import given a unit increase in aggregate import expenditures; conditional expenditure elasticity, $\eta_{i}^{*}=\frac{d \log E_{i}}{d \log E}=1+\alpha_{i} / w_{i}$, which is the additional expenditure on the $i$ th import in percentage terms given a $1 \%$ change in aggregate import expenditures; and Slutsky price elasticity (Chalfant, 1987):

$$
\eta_{i j}^{*}=\frac{d \log q_{i}^{*}}{d \log p_{j}}=-\delta_{i j}+\frac{\beta_{i j}}{w_{i}}+w_{j} .
$$

$\delta_{i j}$ is the Kronecker delta; $\delta_{i j}=1$ when $i=j$ and 0 otherwise. Note that the Slutsky price elasticity $\left(\eta_{i j}^{*}\right)$ measures the impact of a $1 \%$ price change in exporting country $j$ on China's imports from exporting country $i$, holding real aggregate expenditures constant (substitution effect only).

\footnotetext{
${ }^{3}$ Source differentiation need not be because of product differences across countries. For a homogeneous product like soybeans, source differentiation could be because of the risk associated with importing from a particular country (Muhammad, 2012).
} 


\subsection{Modeling trade disruptions}

A feature of China's demand for imported soybeans is periodic disruptions in trade, particularly when importing from Argentina. Disruptions in trade are problematic for import demand analysis because prices do not exist when trade is zero. Following Muhammad (2013) and Kuchler and Arnade (2016), we use a choke-price procedure to account for periods of zero trade and unobserved prices. ${ }^{4}$

To derive choke prices, we start with a general own-price elasticity equation $\left(\eta_{i i}^{*}=\frac{d \log q_{i}}{d \log p_{i}}\right)$ to get the following relationship: $\frac{\underline{q}_{i}-\bar{q}_{i}}{\bar{q}_{i}}=\eta_{i i}^{*} \frac{p_{i}-\bar{p}_{i}}{\bar{p}_{i}}$, which relates percentage deviations from the average quantity to percentage deviations from the average price. Setting ${ }^{\prime}=0$ and then solving for ${ }^{\prime}{ }_{i}$ yields the following:

$$
\dot{p}_{i}=\left(\frac{\eta_{i i}^{*}-1}{\eta_{i i}^{*}}\right) \bar{p}_{i} .
$$

Note that equation (3) is the price at which the quantity decreases from its mean value to zero. Equations (1), (2), and (3) are estimated via a two-step procedure repeated until convergence. See Muhammad (2013) for a more detailed discussion of this estimation procedure.

\subsection{Estimating total import demand}

It is important to account for both trade creation and diversion when analyzing the impact of prices on trade. Export tax reform in Argentina could affect prices in Argentina, resulting in Chinese importers substituting across exporting sources (trade diversion), but price changes could also affect China's aggregate import expenditures (trade creation).

To account for the impact of price changes on aggregate import expenditures, we estimate China's total import demand for soybeans. In this context, total import demand is based on the notion that imported soybean products are (or can be) "resold" to firms within China for further processing. Following Theil (1980), the relationship between total import demand and prices is specified by the following Divisia quantity index relationship:

$$
\Delta \ln \frac{E_{t}}{P_{t}} \cong \Delta Q_{t}=\Theta\left[\Delta \ln p_{t}^{*}-\Delta \ln P_{t}^{\prime}\right] .
$$

The variable $p^{*}$ denotes a representative domestic/output price, which reflects the price that imported soybeans receive if resold in China, and $\Delta \ln P_{t}^{\prime}$ is the Frisch import price index, which is an average measure of import prices. The Frisch import price index is defined as follows:

$$
\Delta \ln P_{t}^{\prime}=\sum_{j} \theta_{j} \Delta \ln p_{j t} .
$$

$\theta_{j}=\frac{\partial E_{j}}{\partial E}$ is the marginal import share for exporting country $j$, and $\Delta \ln p_{j t}=\ln p_{j t}-\ln p_{j t-1}$ is the $j$ th import price in log differences.

$\Theta$ is the Frisch price effect, which is assumed positive because an increase in China's domestic/ output price makes importing soybeans more profitable, holding other factors constant. A positive Frisch price effect also indicates an inverse relationship $(-\Theta)$ between the import price index $\left(\Delta \ln P_{t}^{\prime}\right)$ and China's aggregate import expenditures $\left(\Delta \ln \frac{E_{t}}{P_{t}}\right)$.

We use equations (2), (4), and (5) and the conditional expenditure elasticity $\left(\eta_{i}^{*}\right)$ to derive the unconditional price elasticity:

\footnotetext{
${ }^{4}$ Unit values are often used as proxies for prices, which are zero or nonexistent when trade is zero. Choke prices are the minimum prices required for zero trade (i.e., the price that "chokes" off trade).
} 


$$
\eta_{i j}=\frac{d \log q_{i}}{d \log p_{j}}=-\eta_{i}^{*} \theta_{j} \Theta+\eta_{i j}^{*} .
$$

The first term is the total import effect (trade creation), which is the effect of prices on imports through changes in total import expenditures. The second term is the direct effect of prices on imports as measured by equation (2), which accounts for the substitution across exporting countries because of changes in relative prices (trade diversion).

\subsection{Import demand projections}

We use elasticity-based forecasting equations to make import demand projections (Kastens and Brester, 1996):

$$
q_{i(1)}=\left(\eta_{p *} \frac{p_{(1)}^{*}-p_{(0)}^{*}}{p_{(0)}^{*}}+\sum_{j} \eta_{i j} \frac{p_{j(1)}-p_{j(0)}}{p_{j(0)}}\right) q_{i(0)}+q_{i(0)} .
$$

According to equation (7), the quantity imported from country $i$ in the projection period is a function of the quantity imported during the base period, and the percentage changes in the domestic price and source-specific import prices from the base period to the projection period. ${ }^{5}$

A number of studies have compared model- and elasticity-based forecasts using demand systems (Gustavsen and Rickertsen, 2003; Kastens and Brester, 1996; Muhammad, 2007). All have concluded that demand forecasts using elasticities are superior to model-based forecasts.

For the import demand projections, we assume the full elimination of export taxes and that taxes are fully passed through to import prices. Although this may not be the case, our projections can be considered as upper bound responses. First, we consider a scenario where prices in Argentina are the only prices affected by its export tax reform (short run). Then we consider outcomes where prices in the United States, Brazil, and China respond to price changes in Argentina. To derive the price response across countries, we estimate impulse response functions (IRFs) using a VAR model:

$$
\mathbf{p}_{t}=\mathbf{A}_{0}+\mathbf{A}_{1} \mathbf{p}_{t-1}+\mathbf{A}_{2} \mathbf{p}_{t-2}+\ldots+\mathbf{A}_{k} \mathbf{p}_{t-k}+\boldsymbol{\epsilon}_{t} .
$$

$\mathbf{p}$ is the vector of prices (in levels) for Argentina, Brazil, the United States, and China. $\mathbf{A}_{0}$ is a vector of constants, $\mathbf{A}_{i}$ is a square coefficient matrix, $k$ is the lag order, and $\boldsymbol{\epsilon}$ is a vector of random disturbances. The advantage of using levels is that the estimates remain consistent regardless of prices being integrated or not. Furthermore, standard inference on impulse responses in levels will remain asymptotically valid, and the inference is asymptotically the same even in the presence of cointegrated prices (Lütkepohl and Reimers, 1992; Sims, Stock, and Watson, 1990).

\section{Estimation and results}

\subsection{Data and import demand estimation}

We used quarterly import data (2002:1-2016:4) from the World Trade Atlas (https://www.gtis. $\mathrm{com} / \mathrm{gta} /$ ) to estimate soybean import demand in China by product and exporting source. We considered two products for the analysis: soybeans (HS 1201 soybeans, whether or not broken) and soybean oil (HS 1507 soybean oil and its fractions, whether or not refined, but not chemically modified). The soybean exporting countries included the United States, Brazil, and Argentina, and the soybean oil exporting countries included Brazil, Argentina, and the rest of world (ROW). China's domestic soybean price, provided by the China National Grain and Oils Information Center, was used in estimating total import demand.

\footnotetext{
${ }^{5} \eta_{p *}=d \log q_{i} / d \log p^{*}=\eta_{i}^{*} \Theta$ is the domestic price elasticity, which is the percentage change in the $i$ th import from a $1 \%$ change in the domestic price.
} 
Table 2. Demand elasticities for soybean imports in China

\begin{tabular}{|c|c|c|c|}
\hline Exporter/Product & $\begin{array}{c}\text { Conditional } \\
\text { Expenditure }\left(\eta_{i}^{*}\right)\end{array}$ & $\begin{array}{c}\text { China/Domestic Soybean } \\
\text { Price }\left(\eta_{p^{*}}\right)\end{array}$ & $\begin{array}{l}\text { Unconditional Own } \\
\text { Price }\left(\eta_{i i}\right)\end{array}$ \\
\hline U.S. soybeans & $0.58(0.13)^{\star \star \star}$ & $0.40(0.21)^{\star}$ & $-1.28(0.45)^{\star \star \star}$ \\
\hline Brazilian soybeans & $1.27(0.16)^{\star \star \star}$ & $0.88(0.44)^{\star \star}$ & $-1.75(0.53)^{\star \star \star}$ \\
\hline Argentine soybeans & $1.96(0.23)^{\star \star \star}$ & $1.36(0.67)^{\star \star}$ & $-1.21(0.20)^{\star \star \star}$ \\
\hline Brazilian soybean oil & $0.78(0.34)^{\star \star}$ & $0.54(0.35)$ & $-0.81(0.33)^{\star \star}$ \\
\hline Argentine soybean oil & $0.40(0.26)$ & $0.28(0.22)$ & $-0.85(0.17)^{\star \star \star}$ \\
\hline ROW ${ }^{a}$ soybean oil & $-2.84(1.69)^{\star}$ & $-1.97(1.51)$ & $-1.92(0.84)^{\star \star}$ \\
\hline
\end{tabular}

${ }^{a}$ ROW is the rest of the world.

Notes: Asterisks $\left({ }^{\star \star \star},{ }^{\star \star}\right.$, and $\left.{ }^{\star}\right)$ respectively denote the $0.01,0.05$, and 0.10 significance level. Asymptotic standard errors are in parentheses.

We estimated the import demand system represented by equation (1) using the generalized Gauss-Newton method in TSP (version 5.0), which is a maximum likelihood procedure for equation systems (Hall and Cummins, 2009). We tested and corrected for autoregressive disturbances using a procedure for singular equation systems (Beach and MacKinnon, 1979). The homogeneity and symmetry restrictions were imposed and tested using likelihood ratio tests. Test results indicated that homogeneity and symmetry could not be rejected at the 0.05 significance level. ${ }^{6}$

We assumed the following empirical form for equation (4) to estimate China's total import demand:

$$
\Delta \ln \frac{E_{t}}{P_{t}}=\Theta_{0}+\Theta_{1} \Delta \ln p_{t}^{*}+\Theta_{2} \Delta \ln P_{t}^{\prime}+\sum_{k=1}^{3} \Theta_{i k} d_{k}+\mu_{t} .
$$

Our results show that the estimated domestic/output price effect $\widehat{\Theta}_{1}=0.69(0.33)$ and import price effect $\widehat{\Theta}_{2}=-0.46(0.23)$ are consistent with theory and significant at the 0.05 level. ${ }^{7}$ Estimates indicate that given a $1 \%$ increase in the domestic/output price, China's aggregate expenditures on soybean product imports increase by $0.69 \%$, and given a $1 \%$ increase in the import price level, China's aggregate expenditures on soybean product imports decrease by $0.46 \%$.

\subsection{Import demand elasticities}

The conditional expenditure elasticity $\left(\eta_{i}^{*}\right)$, domestic/output price elasticity $\left(\eta_{p *}\right)$, and unconditional own-price elasticities $\left(\eta_{i i}\right)$ are reported in Table 2.

Recall that the conditional expenditure elasticity $\left(\eta_{i}^{*}=\frac{d \log E_{i}}{d \log E}\right)$ measures the percentage responsiveness of a given import to a $1 \%$ change in China's aggregate import expenditures. Expenditure elasticity estimates are positive and significant for U.S. soybeans (0.58), Brazilian soybeans (1.27), Argentine soybeans (1.96), and Brazilian soybean oil (0.78). The expenditure elasticities for Argentina and Brazil are larger than the United States reflecting the fact that overall import growth in China has been because of relatively larger increases in imports from Latin America. The negative estimate for ROW soybean oil (-2.84) is likely the result of being a residual category rather than being an inferior product in the Chinese market.

The domestic/output price elasticity $\left(\eta_{p *}=\frac{d \log q_{i}}{d \log p^{*}}\right)$ measures how a $1 \%$ increase in China's domestic price affects imports from each country. The results indicate that Argentine soybeans are

\footnotetext{
${ }^{6}$ Log-likelihood values for the unrestricted, homogeneity constrained, and homogeneity and symmetry constrained models were 583.20, 577.68, and 570.73, respectively. The chi-square test statistic for homogeneity was 11.05 , which is less than $\chi^{2}(5)=11.07, P<0.05$. The chi-square test statistic for symmetry, given homogeneity, was 13.90 , which is less than $\chi^{2}(10)=18.31, P<0.05$.

${ }^{7}$ Standard errors are in parentheses.
} 
Table 3. Unconditional cross-price elasticities $\left(\eta_{i j}\right)$ for soybean imports in China

\begin{tabular}{|c|c|}
\hline Quantity/Price & Estimate (SE) \\
\hline U.S. soybeans/Brazilian soybeans & $0.85(0.42)^{\star \star}$ \\
\hline U.S. soybeans/Argentine soybeans & $0.14(0.09)$ \\
\hline U.S. soybeans/Brazilian soybean oil & $-0.02(0.07)$ \\
\hline U.S. soybeans/Argentine soybean oil & $0.04(0.07)$ \\
\hline U.S. soybeans/ROW ${ }^{a}$ soybean oil & $-0.01(0.05)$ \\
\hline Brazilian soybeans/U.S. soybeans & $1.04(0.51)^{\star \star}$ \\
\hline Brazilian soybeans/Argentine soybeans & $0.01(0.14)$ \\
\hline Brazilian soybeans/Brazilian soybean oil & $0.01(0.08)$ \\
\hline Brazilian soybeans/Argentine soybean oil & $0.03(0.08)$ \\
\hline Brazilian soybeans/ROW soybean oil & $0.06(0.06)$ \\
\hline Argentine soybeans/U.S. soybeans & $0.39(0.24)$ \\
\hline Argentine soybeans/Brazilian soybeans & $0.02(0.31)$ \\
\hline Argentine soybeans/Brazilian soybean oil & $-0.05(0.04)$ \\
\hline Argentine soybeans/Argentine soybean oil & $-0.01(0.06)$ \\
\hline Argentine soybeans/ROW soybean oil & $-0.05(0.04)$ \\
\hline Brazilian soybean oil/U.S. soybeans & $-0.37(1.11)$ \\
\hline Brazilian soybean oil/Brazilian soybeans & $0.14(1.05)$ \\
\hline Brazilian soybean oil/Argentine soybeans & $-0.28(0.23)$ \\
\hline Brazilian soybean oil/Argentine soybean oil & $0.52(0.22)^{\star \star}$ \\
\hline Brazilian soybean oil/ROW soybean oil & $0.42(0.15)^{\star \star \star}$ \\
\hline Argentine soybean oil/U.S. soybeans & $0.28(0.54)$ \\
\hline Argentine soybean oil/Brazilian soybeans & $0.17(0.51)$ \\
\hline Argentine soybean oil/Argentine soybeans & $-0.02(0.17)$ \\
\hline Argentine soybean oil/ Brazilian soybean oil & $0.23(0.10)^{\star \star}$ \\
\hline Argentine soybean oil/ROW soybean oil & $-0.01(0.09)$ \\
\hline ROW soybean oil/U.S. soybeans & $-0.83(3.94)$ \\
\hline ROW soybean oil/Brazilian soybeans & $3.67(3.89)$ \\
\hline ROW soybean oil/Argentine soybeans & $-1.41(1.09)$ \\
\hline ROW soybean oil/Brazilian soybean oil & $1.90(0.69)^{\star \star \star}$ \\
\hline ROW soybean oil/Argentine soybean oil & $-0.12(0.88)$ \\
\hline
\end{tabular}

aROW is the rest of the world.

Notes: Asterisks $\left({ }^{* \star *}\right.$ and $\left.{ }^{* \star}\right)$ respectively denote the 0.01 and 0.05 significance level. Asymptotic standard errors (SE) are in parentheses.

the most responsive to an increase in China's domestic price (1.36). The responsiveness of Brazilian soybeans $(0.88)$ and U.S. soybeans $(0.40)$ to the domestic price is significantly smaller. The responsiveness of soybean oil imports to the domestic price is insignificant for all exporting sources.

The unconditional own-price elasticities $\left(\eta_{i i}=\frac{d \log q_{i}}{d \log p_{i}}\right)$ indicate that Chinese demand for imported soybeans is relatively more elastic than soybean oil. The unconditional own-price elasticities for soybeans range from -1.75 for Brazil to -1.21 for Argentina. Comparably smaller in 

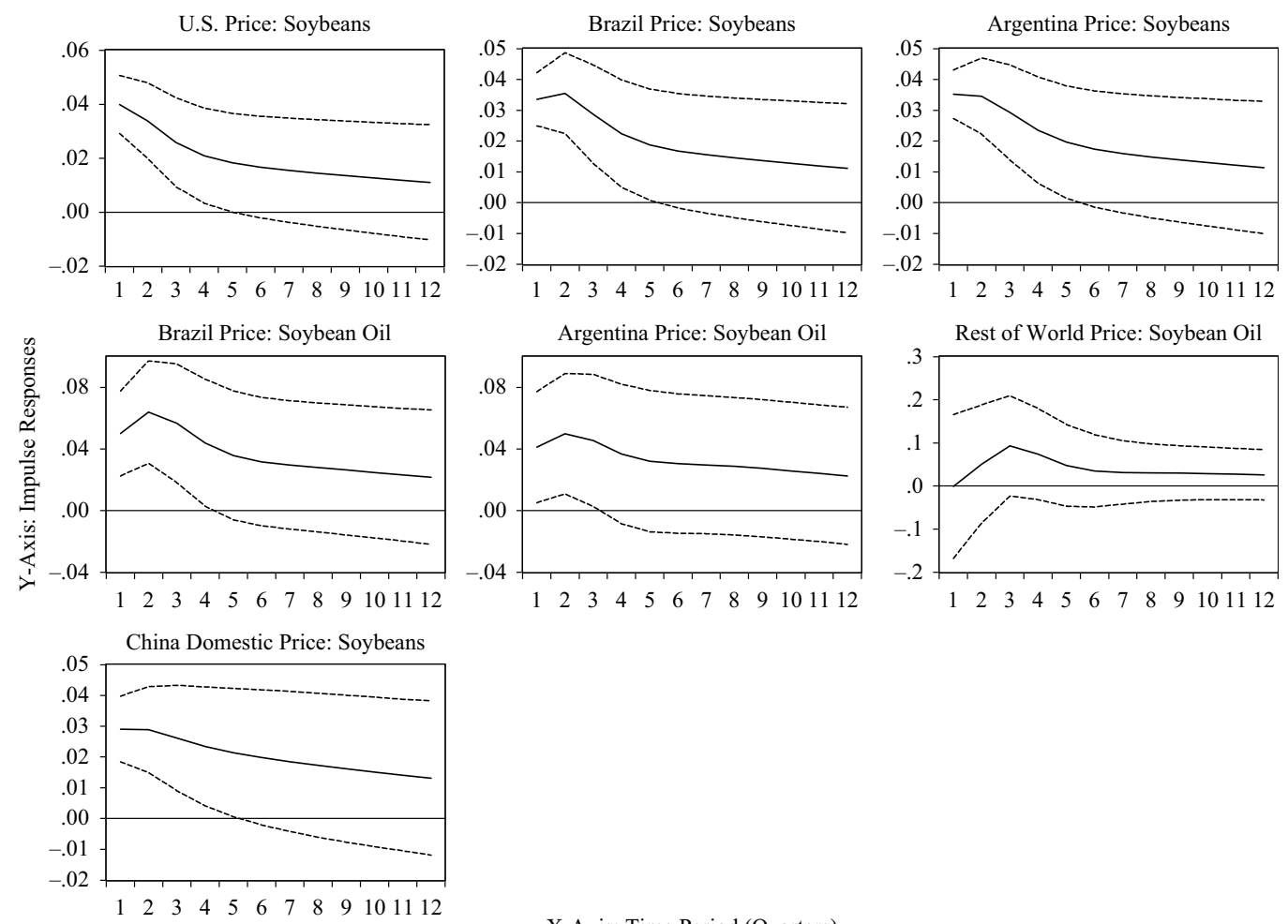

X-Axis: Time Period (Quarters)

Figure 3. Generalized impulse responses to innovations in soybean prices in Argentina. Notes: Vertical axes measure generalized standard-deviation impulses as described by Pesaran and Shin (1998). The 95\% confidence bans (dotted lines) are based on Monte Carlo standard errors.

magnitude are the unconditional own-price elasticities for soybean oil: Brazil $(-0.81)$ and Argentina (-0.85). ROW soybean oil is the most sensitive to own-price changes $(-1.92)$, likely because of China's relatively small imports from ROW.

The unconditional cross-price elasticities $\left(\eta_{i j}=\frac{d \log q_{i}}{d \log p_{j}}\right)$ are reported in Table 3. Results indicate that the relationship between countries and products are mostly insignificant. Exceptions include substitute relationships between soybeans from the United States and Brazil, soybean oil from Brazil and Argentina, and soybean oil from Brazil and ROW.

\subsection{VAR estimation and impulse response functions}

IRFs, based on generalized standard-deviation impulses as described by Pesaran and Shin (1998), are used to assess the impact of price shocks in Argentina on prices in other countries. IRFs for soybean price shocks in Argentina are shown in Figure 3, and IRFs for soybean oil price shocks in Argentina are shown in Figure 4.

Note that after a soybean price shock in Argentina (Figure 3), soybean prices in the United States, Brazil, and China and soybean oil prices in Brazil and Argentina respond similarly. However, the confidence bans for the responsiveness of soybean oil prices in Argentina are comparably large. After the fifth quarter, the confidence bans for all prices include the zero axis, which is an indication that the responses to soybean price shocks in Argentina are not long lasting.

Results are even less compelling for soybean oil price shocks in Argentina (Figure 4) where soybean oil prices in Brazil are significantly affected, but responses for the remaining products and countries are insignificant by the first quarter. 

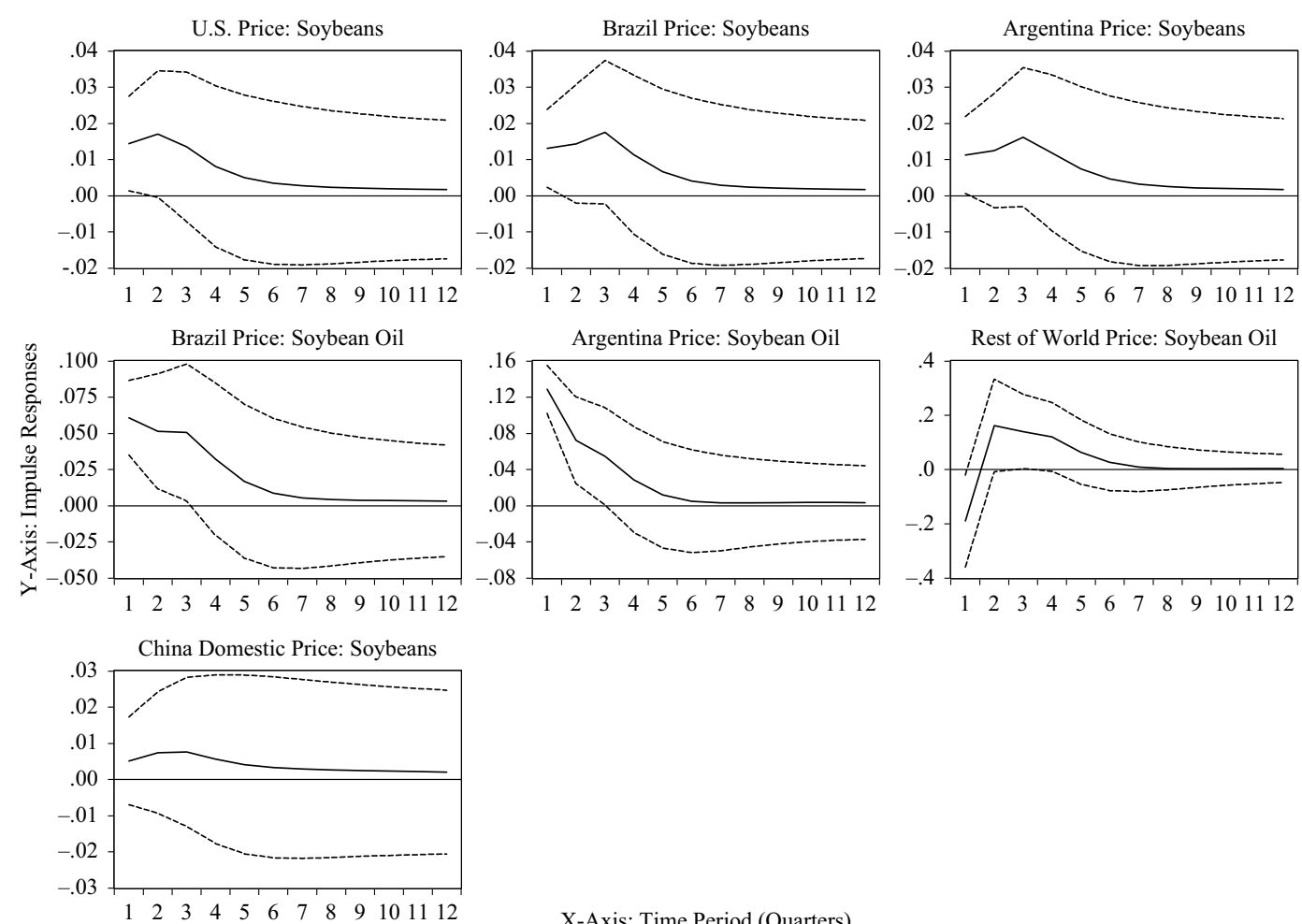

X-Axis: Time Period (Quarters)

Figure 4. Generalized impulse responses to innovations in soybean oil prices in Argentina. Notes: Vertical axes measure generalized standard-deviation impulses as described by Pesaran and Shin (1998). The 95\% confidence bans (dotted lines) are based on Monte Carlo standard errors.

\subsection{Import demand projections}

We conducted import demand projections assuming the following: (1) prices in Argentina are the only prices affected by its export tax reform (short-run projections); (2) prices in Brazil, the United States, and China experience the largest possible response to Argentina's export tax reform based on the estimated responses in Figures 3 and 4 (peak response projections); and (3) prices in all countries reach their long-run equilibrium based on the estimated responses in Figures 3 and 4 (long-run projections).

We assume the full elimination of export taxes and that export taxes are fully passed through to import prices in China. Monte Carlo simulations are used to derive 95\% confidence intervals (CIs) of import responsiveness. All projections are compared to the baseline (3-year annual average: 2014-2016).

Projection results are reported in Table 4. Assuming that prices in Argentina are the only prices affected by its export tax reform (short-run projections), results indicate that the elimination of export taxes in Argentina will have a negligible effect on China's soybean product imports. Imports from Argentina are projected to increase because of relatively lower prices, which is to be expected. However, we find insignificant changes for the United States and Brazil.

The confidence intervals for the quantity changes ( $\Delta$ Quantity) include zero for all countries except Argentina. Chinese imports of Argentine soybeans are projected to increase by 2,475 thousand MT [95\% CI: 1,660, 3,287], and Argentine soybean oil by 71 thousand MT [95\% CI: 37, 105]. Projected expenditure changes ( $\Delta$ Expenditure) for Argentina are negative because of China 
Table 4. China's soybean import demand projection given the elimination of export taxes in Argentina

\begin{tabular}{|c|c|c|c|c|c|c|}
\hline \multirow[b]{2}{*}{ Country Product } & \multicolumn{2}{|c|}{ Baseline } & \multicolumn{4}{|c|}{ Short-Run Projections } \\
\hline & $\begin{array}{c}\text { Quantity } \\
\text { (thousand MT) }\end{array}$ & $\begin{array}{c}\text { Expenditure } \\
\text { (million \$) }\end{array}$ & Quantity (thousand MT) & $\Delta$ Quantity (thousand MT) & Expenditure (million \$) & $\Delta$ Expenditure (million \$) \\
\hline Brazilian soybeans & 36,722 & 17,119 & $35,068[33,135,37,052]$ & $-1,654[-3,587,330]$ & $16,349[15,440,17,270]$ & $-770[-1,679,151]$ \\
\hline U.S. soybeans & 30,700 & 14,180 & $30,429[28,087,32,806]$ & $-271[-2,613,2,106]$ & $14,055[13,002,15,139]$ & $-125[-1,178,959]$ \\
\hline Argentine soybeans & 7,818 & 3,511 & $10,293[9,478,11,105]$ & $2,475[1,660,3,287]$ & $3,421[3,156,3,700]$ & $-90[-355,189]$ \\
\hline Brazilian soybean oil & 316 & 273 & $300[254,345]$ & $-16[-62,29]$ & $259[220,299]$ & $-14[-53,26]$ \\
\hline Argentine soybean oil & 335 & 289 & $406[372,440]$ & $71[37,105]$ & $266[243,288]$ & $-23[-46,-1]$ \\
\hline ROW ${ }^{\mathrm{a}}$ soybean oil & 187 & 168 & $261[140,377]$ & $74[-47,190]$ & $234[128,338]$ & $66[-40,170]$ \\
\hline \multirow[t]{2}{*}{ Total } & 76,078 & 35,540 & $76,757[71,466,82,125]$ & $679[-4,612,6,047]$ & $34,584[32,189,37,034]$ & $-956[-3,351,1,494]$ \\
\hline & & & \multicolumn{4}{|c|}{ Peak Response Projections } \\
\hline Brazilian soybeans & 36,722 & 17,119 & $36,777[33,837,39,588]$ & $55[-2,885,2,866]$ & $12,516[11,516,13,477]$ & $-4,603[-5,603,-3,642]$ \\
\hline U.S. soybeans & 30,700 & 14,180 & $31,315[26,927,35,610]$ & $615[-3,773,4,910]$ & $10,559[9,054,12,024]$ & $-3,621[-5,126,-2,156]$ \\
\hline Argentine soybeans & 7,818 & 3,511 & $6,766[4,590,8,845]$ & $-1,052[-3,228,1,027]$ & $2,249[1,547,2,949]$ & $-1,262[-1,964,-562]$ \\
\hline Brazilian soybean oil & 316 & 273 & $347[288,404]$ & $31[-28,88]$ & $228[190,267]$ & $-45[-83,-6]$ \\
\hline Argentine soybean oil & 335 & 289 & $314[262,364]$ & $-21[-73,29]$ & $206[172,239]$ & $-83[-117,-50]$ \\
\hline ROW soybean oil & 187 & 168 & $35[-191,264]$ & $-152[-378,77]$ & $31[-172,243]$ & $-137[-340,75]$ \\
\hline \multirow[t]{2}{*}{ Total } & 76,078 & 35,540 & $75,554[65,713,85,075]$ & $-524[-10,365,8,997]$ & $25,789[22,307,29,199]$ & $-9,751[-13,233,-6,341]$ \\
\hline & & & \multicolumn{4}{|c|}{ Long-Run Projections } \\
\hline Brazilian soybeans & 36,722 & 17,119 & $36,099[32,640,39,470]$ & $-623[-4,082,2,748]$ & $16,829[15,187,18,388]$ & $-290[-1,932,1,269]$ \\
\hline U.S. soybeans & 30,700 & 14,180 & $29,647[23,704,35,464]$ & $-1,053[-6,996,4,764]$ & $13,694[11,007,16,343]$ & $-486[-3,173,2,163]$ \\
\hline Argentine soybeans & 7,818 & 3,511 & $6,824[4,899,8,659]$ & $-994[-2,919,841]$ & $3,065[2,221,3,907]$ & $-446[-1,290,396]$ \\
\hline Brazilian soybean oil & 316 & 273 & $287[224,347]$ & $-29[-92,31]$ & $248[193,301]$ & $-25[-80,28]$ \\
\hline Argentine soybean oil & 335 & 289 & $333[301,364]$ & $-2[-34,29]$ & $288[260,313]$ & $-1[-29,24]$ \\
\hline ROW soybean oil & 187 & 168 & $59[31,87]$ & $-128[-156,-100]$ & $53[28,78]$ & $-115[-140,-90]$ \\
\hline Total & 76,078 & 35,540 & $73,249[61,799,84,391]$ & $-2,829[-14,279,8,313]$ & $34,177[28,896,39,330]$ & $-1,363[-6,644,3,790]$ \\
\hline
\end{tabular}

aROW is the rest of the world.

Notes: Baseline quantities and expenditures are 3-year (2014-2016) annual averages. The 95\% confidence intervals, in square brackets, are based on Monte Carlo simulations. MT, metric tons. 
paying a lower import price when taxes are eliminated. However, the confidence intervals indicate that the projected expenditure changes are not significantly different from zero. This does not necessarily imply that Argentine producers will receive no additional revenue from export tax reform. Considering that as much as a quarter of baseline expenditures for Argentina is government revenue, actual producer revenue could still increase.

Assuming that prices in Brazil, the United States, and China experience the largest possible response to Argentina's export tax reform (peak response projections), results indicate insignificant changes in the quantity of China's soybean and soybean oil imports, in total and by exporting country. However, lower prices overall result in significant declines in import values across all countries including a decline in total imports of $-\$ 9,751$ million [95\% CI: $-\$ 13,233$, $-\$ 6,341]$. This is not surprising because all prices fall under this scenario. The decline in China's expenditures on imports from the United States and Brazil could represent loss revenue for these countries, with U.S. soybeans ( $-\$ 4,603$ million) and Brazilian soybeans $(-\$ 3,621$ billion) showing the largest projected declines.

Assuming that prices across all countries reached their long-run equilibrium, which is essentially a return to their initial levels according to the VAR estimates (long-run projections), results suggest that export tax reform in Argentina will likely have a negligible impact on China's soybean product imports in the long run. Although imports of ROW soybean oil are projected to decline, projected changes for the United States, Brazil, and Argentina are not significantly different from zero. Even the point estimates are relatively small when compared with the baseline. For instance, the projected change for U.S. soybeans $(-1,053$ thousand MT) is only about $3 \%$ of the baseline quantity $(30,700$ thousand MT).

\section{Summary and conclusion}

Following the United States and Brazil, Argentina is the third largest exporter of soybeans to China. All else being equal, the elimination of export taxes in Argentina could make its soybean products more competitive in the Chinese market, affecting competing exporting countries like the United States and Brazil. Our primary goal was to address this issue. In this particular case (soybean product imports in China), our results indicated that Argentina could realize some gains in the short run when its prices are relatively lower than competing countries. However, results also indicated that price shocks in Argentina do not have permanence in global soybean markets and that any resulting price change because of export tax elimination would be relatively short lived. Consequently, projected changes in Chinese imports in the long run were insignificant, even for imports from Argentina.

Our results suggest that gains from soybean export tax reform are more likely to be realized within Argentina but not globally. The reason being that Argentina is a relatively small soybean exporter when compared with the United States and Brazil, so its price leadership potential is somewhat limited. Furthermore, although soybeans are relatively homogeneous across countries, cross-price effects for Argentina were mostly insignificant suggesting that relatively lower prices do not lead to substitutions in favor of Argentina's soybean products.

Although the results of this study address key questions about how export taxes in Argentina could affect Chinese import demand, there are limitations to our analysis. We do not account for adjustments in other feed and oilseed sectors, as well as the net effects of decreased exports to other destination markets. For instance, increased soybean exports to China could be offset by decreased exports to other countries or decreased exports in related feed grain and oilseed markets. That said, we do show that concerns within the United States and Brazil about the global competitiveness of Argentina's soybean products because of export tax reform may not be warranted. 
Author ORCIDs. (DD Andrew Muhammad 0000-0002-4825-9324

Acknowledgments. This paper was greatly improved by comments and suggestions from the editor and three anonymous reviewers.

Financial support. This research was supported by the U.S. Department of Agriculture, Foreign Agricultural Service, Emerging Markets Program (Project: Assessing Argentina's Market Potential - Agreement FX18TA-10960R028 with the University of Tennessee).

\section{References}

Armington, P.S. “A Theory of Demand for Products Distinguished by Place of Production.” International Monetary Fund Staff Papers 16, 1(1969):159-78.

Beach, C.M., and J.G. MacKinnon. "Maximum Likelihood Estimation of Singular Equation Systems with Autoregressive Disturbances.” International Economic Review 20, 2(1979):459-64.

Bouët, A., C. Estrades, and D. Laborde. "Differential Export Taxes along the Oilseeds Value Chain: A Partial Equilibrium Analysis." American Journal of Agricultural Economics 96, 3(2014):924-38.

Chalfant, J.A. "A Globally Flexible, Almost Ideal Demand System." Journal of Business and Economic Statistics 5, 2(1987):233-42.

Chen, W., M. Marchant, and A. Muhammad. "China's Soybean Product Imports: An Analysis of Price Effects Using a Production System Approach.” China Agricultural Economic Review 4, 4(2012):499-513.

Cicowiez, M., C. Díaz-Bonilla, and E. Díaz-Bonilla. "Impacts of Trade Liberalization on Poverty and Inequality in Argentina: Policy Insights from a Non-Parametric CGE Microsimulation Analysis." International Journal of Microsimulation 3, 1(2010):118-22.

Deaton, A., and J. Muellbauer. “An Almost Ideal Demand System.” American Economic Review 70, 3(1980):312-26.

Deese, W., and J. Reeder. "Export Taxes on Agricultural Products: Recent History and Economic Modeling of Soybean Export Taxes in Argentina." Journal of International Commerce and Economics 2007, Web version (2007):1-29.

Gustavsen, G.W., and K. Rickertsen. "Forecasting Ability of Theory-Constrained Two-Stage Demand Systems." European Review of Agricultural Economics 30, 4(2003):539-58.

Hall, B.H., and C. Cummins. Reference Manual Version 5.0. Palo Alto, CA: TSP International, 2009.

Kastens, T.L., and G.W. Brester. "Model Selection and Forecasting Ability of Theory-Constrained Food Demand Systems." American Journal of Agricultural Economics 78, 2(1996):301-12.

Kuchler, F., and C. Arnade. “Consumers' Welfare and Off-Season Produce Imports." European Review of Agricultural Economics 43, 4(2016):585-608.

Lütkepohl, H., and H.-E. Reimers. "Impulse Response Analysis of Cointegrated Systems." Journal of Economic Dynamics and Control 16, 1(1992):53-78.

Matsuda, T. "Differential Demand Systems: A Further Look at Barten's Synthesis." Southern Economic Journal 71, 3(2005):607-19.

Meilke, K., M. Wensley, and M. Cluff. “The Impact of Trade Liberalization on the International Oilseed Complex.” Review of Agricultural Economics 23, 1(2001):2-17.

Muhammad, A. “The Impact of Increasing Non-Agricultural Market Access on EU Demand for Imported Fish: Implications for Lake Victoria Chilled Fillet Exports.” European Review of Agricultural Economics 34, 4(2007):461-77.

Muhammad, A. "Source Diversification and Import Price Risk." American Journal of Agricultural Economics 94, 3(2012): 801-14.

Muhammad, A. "Estimating Import Demand in the Presence of Seasonal Trade and Unobserved Prices." Applied Economics Letters 20, 5(2013):446-51.

Muhammad, A., and S.A. Smith. Evaluating the Impact of Retaliatory Tariffs on U.S. Soybeans in China. Knoxville: University of Tennessee Institute of Agriculture, Extension Report W532, 2018.

Pesaran, H.H., and Y. Shin. “Generalized Impulse Response Analysis in Linear Multivariate Models." Economics Letters 58, 1(1998):17-29.

Pirovano, F. Argentina Grain and Feed Annual Report. Washington, DC: U.S. Department of Agriculture, Foreign Agricultural Service, AR9005, 2009.

Regúnaga, M., and A.T. Rodriguez. "Argentina's Agricultural Policies, Trade, and Sustainable Development Objectives." Issue Paper 55, Geneva: International Centre for Trade and Sustainable Development, 2015.

Sandoval, L. Argentina Oilseed and Products Update. Washington, DC: U.S. Department of Agriculture, Foreign Agricultural Service, 2016.

Sandoval, L. Argentina Government Reshuffles Cabinet and Introduces New Export Taxes. Washington, DC: U.S. Department of Agriculture, Foreign Agricultural Service, 2018. 
Sandoval, L., and K. Joseph. Argentina New Government Lifts Currency Controls and Cuts Export Taxes. Washington, DC: U.S. Department of Agriculture, Foreign Agricultural Service, 2015.

Seale, J.L., M.A. Marchant, and A. Basso. "Imports versus Domestic Production: A Demand System Analysis of the U.S. Red Wine Market." Review of Agricultural Economics 25, 1(2003):187-202.

Sims, C.A., J.H. Stock, and M.W. Watson. "Inference in Linear Time Series Models with Some Unit Roots." Econometrica 58, 1(1990):113-44.

Sullivan, M.P., and R.M. Nelson. Argentina: Background and U.S. Relations. Washington, DC: Congressional Research Service, R43816, 2017.

Taheripour, F., and W.E. Tyner. "Impacts of Possible Chinese 25\% Tariff on U.S. Soybeans and Other Agricultural Commodities." Choices 33, 2(2018):1-7.

Theil, H. The System-Wide Approach to Microeconomics. Chicago: University of Chicago Press, 1980.

Toulan, O.N. "Measuring the Impact of Market Liberalization on Export Behavior: The Case of Argentina." International Trade Journal 16, 1(2002):105-28.

Cite this article: Muhammad A and Valdes C (2019). Export Tax Reform and the Competitiveness of Imported Soybeans in China. Journal of Agricultural and Applied Economics 51, 511-525. https://doi.org/10.1017/aae.2019.15 